\title{
Fitness components of Monosporascus cannonballus isolates from northeastern Brazilian melon fields
}

\author{
Kamila C. Correia ${ }^{1}$, Erlen K. C. Silva ${ }^{1}$, Marcos P. S. Câmara ${ }^{1}$, Rui Sales Jr. ${ }^{2}$, Eduardo S. G. Mizubuti ${ }^{3}$, \\ Josep Armengol ${ }^{4}$, José García-Jiménez ${ }^{4}$ \& Sami J. Michereff ${ }^{1}$
}

${ }^{1}$ Departamento de Agronomia, Universidade Federal Rural de Pernambuco, Av. Dom Manoel de Medeiros s/n, 52171-900, Recife, PE, Brazil; ${ }^{2}$ Departamento de Ciências Vegetais, Universidade Federal Rural do Semiárido, Cx. Postal 137, 59625900, Mossoró, RN, Brazil; ${ }^{3}$ Departamento de Fitopatologia, Universidade Federal de Viçosa, 36570-900, Viçosa, MG, Brazil; ${ }^{4}$ Instituto Agroforestal Mediterráneo, Universidad Politécnica de Valencia, Camino de Vera s/n, 46022, Valencia, Spain

Author for correspondence: Sami J. Michereff, e-mail: sami@depa.ufrpe.br

\begin{abstract}
Monosporascus root rot and vine decline caused by Monosporascus cannonballus is one of the most important melon yieldlimiting diseases in northeastern Brazil. This study investigated the fitness components of 57 isolates of M. cannonballus obtained from Brazilian melon fields by evaluating: i) their mycelial growth rate (MGR), and perithecia and ascospore production (PP and AP) on potato dextrose agar (PDA); ii) their sensitivity to the fungicide fluazinam; and iii) their virulence to melon seedlings. All M. cannonballus isolates showed variability in their MGR, PP and AP values. They were sensitive to the fungicide fluazinam, showing some degree of mycelial growth inhibition (MGI), and were pathogenic to melon seedlings, with a mean disease severity index (DSI) of 62.1\%. By univariate analysis, the formation of groups of similarity amongst the isolates of $M$. cannonballus within each variable was not limited by the area of origin of each isolate, given that in most situations, different isolates of the same area were distributed into distinct groups of similarity. A multivariate cluster analysis allowed the separation of the $57 \mathrm{M}$. cannonballus isolates in 18 groups of similarity. The fitness variability among $M$. cannonballus isolates found in this study should be considered when possible sources of resistance are evaluated in melon breeding programs.

Key words: Cucumis melo, ascospore production, Monosporascus root rot, mycelial growth, perithecial virulence, sensitivity to fungicide.
\end{abstract}

\section{INTRODUCTION}

The northeastern region of Brazil accounts for $95 \%$ of melon (Cucumis melo L.) production in this country, covering approximately 16,300 ha. The main producing areas are located in the states of Rio Grande do Norte with 7,943 ha and a production of 242,303 t, and Ceará with 5,431 ha and a production of 153,161 t (AGRIANUAL, 2013). In recent years, the expansion of the cultivated area, coupled with intensive and continuous cultivation of melon without crop rotation, has contributed to the increased incidence of fungal diseases affecting the root system. Monosporascus root rot and vine decline (MRRVD) caused by the soilborne ascomycete Monosporascus cannonballus Pollack \& Uecker is one of the most important melon yield-limiting diseases in the Brazilian northeast (Silva et al., 2010; Bezerra et al., 2013), as in other melon-production regions located in hot semi-arid to arid regions, as well as subtropical environments worldwide (Martyn \& Miller, 1996; Cohen et al., 2000; Cohen et al., 2012; Ben Salem et al., 2013).

Monosporascus cannonballus was first detected in Brazil in 2002, affecting melon plants cultivated in the agricultural areas of Ceará and Rio Grande do Norte states
(Sales Jr. et al., 2004). Symptoms of the disease include the yellowing and death of the crown leaves, which gradually radiates out and kills the vine as the fruit approach maturity. M. cannonballus produces ascospores in perithecia formed on diseased roots at the end of the growing season (Martyn \& Miller, 1996; Cohen et al., 2012). Ascospores function as the primary survival structure, as well as the primary inoculum of the fungus for root infection (Stanghellini et al., 1996; 2000; 2010).

No melon cultivar resistant to $M$. cannonballus is commercially available (Fita et al., 2009; Cohen et al., 2012) and chemical control of this pathogen in many circumstances has been unsatisfactory and/or uneconomical (Cohen et al., 2000; Fita et al., 2007; Cohen et al., 2012). Currently, in Brazil there are no fungicides registered for the control of MRRVD (AGROFIT, 2013).

Knowledge of the variability in the pathogen population and the levels of host resistance are essential factors for developing strategies for the management of root diseases of melon. The success of breeding programs needs extensive knowledge about the pathogen variability. Consequently, this aspect should be investigated before selecting sources of resistance in the host (Bruton, 1998). 
Various phenotypic and genotypic markers can be used to study the variation within and among plant pathogen populations. Nowadays, molecular markers are widely used to investigate the genetic diversity in plant pathogen populations (Linde, 2010). However, the pathogen populations may consist of genotypes with different fitness, defined as the ability of a pathogen to survive and reproduce (Antonovics \& Alexander, 1989; Dyakov et al., 2007). Fitness is a relative concept, where individuals are ranked according to their contribution to the population in the subsequent generation. Therefore, individuals with greater fitness leave more descendants in the subsequent generation (Lannou, 2012).

The competitive ability and relative fitness of a pathogen strain are determined by its intrinsic biological properties, the resistance and heterogeneity of the corresponding host population, the population density and genetic relatedness of the competing strains, and the physical environment. Competitive ability can be inferred indirectly from fitness components (Zhan \& McDonald, 2013). Because fitness is relative, it must be estimated by measuring characters that constrain some adaptive advantage among individuals. Phenotypic markers, like mycelial growth rate, reproductive potential, sensitivity to fungicides and virulence, are useful for assessment of fitness variability in plant pathogen populations (Antonovics \& Alexander 1989; Allen et al., 1999; Brown, 2006; Lannou, 2012).

Despite the importance of MRRVD worldwide, fitness components of M. cannonballus populations have not been properly studied. Thus, the objective of this study was to investigate the fitness components of $57 \mathrm{M}$. cannonballus isolates collected in melon growing areas of northeastern Brazil by evaluating: i) their mycelial growth rate, and perithecia and ascospore production at three temperatures, ii) their sensitivity to the fungicide fluazinam, and iii) their virulence to melon seedlings.

\section{MATERIALS AND METHODS}

\section{Fungal isolates}

Fifty-seven M. cannonballus isolates were obtained in 2009 from roots of melon plants exhibiting symptoms of MRRVD in seven growing areas of the Brazilian northeastern region, located in the agricultural centers of Icapuí and Quixeré (Ceará state), and Mossoró (Rio Grande do Norte state) (Table 1). All isolates were hyphaltipped and stored at $25^{\circ} \mathrm{C}$ in darkness in plastic vials containing sterilized peat (Fertalon Fertilizantes Londrina Ltda.). The isolates were identified morphologically as M. cannonballus after growing them on potato dextrose agar (PDA) (Acumedia Co.) and V8-juice agar $(100 \mathrm{ml}$ of $\mathrm{V} 8$ juice, $1 \mathrm{~g}$ of $\mathrm{CaCO}_{3}, 18 \mathrm{~g}$ of agar, and $900 \mathrm{ml}$ of sterile distilled water) for two months at $28^{\circ} \mathrm{C}$ in darkness (Sivanesan, 1991). Additionally, the internal transcribed spacer (ITS nrDNA) region, fragments of the translation elongation factor 1-alpha (EF-1 $\alpha)$ and the $\beta$-tubulin ( $\beta$-tub) genes were used to confirm the identification of three representative isolates through BLAST searches (http:// www.ncbi.nlm.nih.gov/BLAST/). The representative sequences of the studied ITS region of isolates CMM-2401, CMM-2429 and CMM-2365 were deposited in GenBank (JQ762362, JQ762366 and JQ762367, respectively). These sequences have $99.00 \%$ similarity with the sequence of $M$. cannonballus (AM167936). The isolates were deposited in the Culture Collection of Phytopathogenic Fungi "Prof. Maria Menezes" (CMM) of the Universidade Federal Rural de Pernambuco (Recife, Brazil).

All experiments were conducted twice. Prior to use, a small portion of the colonized peat from each plastic vial was transferred to potato dextrose agar PDA plates and allowed to grow at $25^{\circ} \mathrm{C}$ in darkness.

\section{Mycelial growth, and perithecia and ascospore production at different temperatures}

The mycelial growth, and perithecia and ascospore production of $M$. cannonballus isolates were determined using cultures grown on PDA. Mycelial plugs $(6 \mathrm{~mm}$ in diameter) obtained from the growing edge of the colonies were transferred to the center of PDA plates, which were then incubated in darkness at temperatures of 22,28 and $38^{\circ} \mathrm{C}$. There were four replicates for each isolate and temperature combination. The diameter of each colony was measured twice perpendicularly when it reached at least two thirds

TABLE 1 - Geographical origin of Monosporascus cannonballus isolates used in this study, obtained from melon plants in northeastern Brazil.

\begin{tabular}{|c|c|c|c|}
\hline Codes (CMM) ${ }^{1}$ & State & $\begin{array}{c}\text { Agricultural } \\
\text { area }\end{array}$ & $\begin{array}{c}\text { Growing } \\
\text { site }\end{array}$ \\
\hline $2362,2363,2365,2369,2370,2371,2372$ & Ceará & Icapuí & I \\
\hline $2401,2402,2403,2405,2430,2431,2466$ & Ceará & Quixeré & II \\
\hline $2376,2379,2380,2381,2382,2427,2429$ & Rio Grande do Norte & Mossoró & III \\
\hline $2386,2387,2389,2390,2391,2394,2395,2396,2397$ & Rio Grande do Norte & Mossoró & IV \\
\hline $2434,2435,2436,2437,2438,2439,2441,2443,2444$ & Rio Grande do Norte & Mossoró & V \\
\hline $2408,2411,2412,2414,2418,2421,2422,2446$ & Rio Grande do Norte & Mossoró & VI \\
\hline $2448,2449,2450,2451,2452,2453,2454,2455,2457,2467$ & Rio Grande do Norte & Mossoró & VII \\
\hline
\end{tabular}

${ }^{1}$ Culture Collection of Phytopathogenic Fungi "Prof. Maria Menezes" (CMM) of the Universidade Federal Rural de Pernambuco (Recife, PE, Brazil). 
of the plate and used to calculate the mycelial growth rate (MGR) as mm per day. Colonies were further incubated until 45 days for perithecia formation and quantification as described by Cluck et al. (2009). Four plugs (12 mm diameter) were randomly selected and removed from each colony, and each plug was considered a replicate (16 plugs per isolate). Each plug was placed between two clear glass slides and flattened in order to observe and count the perithecia under a low power stereoscope. Each plug consisted of a volume of $0.395 \mathrm{~cm}^{3}$ and the number of perithecia produced (PP) was expressed as perithecia per $\mathrm{cm}^{3}$. Colonies were further incubated until 50 days, when perithecia were removed and transferred to clear glass slides for ascospore quantification. Ten perithecia were randomly selected and removed from each colony and each of them was considered a replicate ( 40 perithecia per isolate). Each perithecia was placed between two clear glass slides and flattened in order to observe and count the number of ascospores produced (AP). Ascospores were observed under a microscope at $40 \times$ magnification.

\section{Sensitivity to fungicide fluazinam}

The sensitivity of $M$. cannonballus isolates to the fungicide fluazinam was determined in vitro. Sterile aqueous solution of fluazinam was mixed with PDA to give concentration of $10 \mu \mathrm{g}$ a.i./L. The selection of this fungicide and the discriminatory concentration was based on preliminary tests (unpublished data), which evaluated the inhibitory effect of five doses of the five active ingredients on seven M. cannonballus isolates, as well as in other studies which evaluated the in vitro inhibitory effect of different fungicides against this fungi (Cohen et al., 1999; Pivonia et al., 2010). A mycelial plug (6 mm diameter) from a 15-day old M. cannonballus culture was placed in the center of the Petri dish containing the test fungicide. The cultures were incubated at $28^{\circ} \mathrm{C}$ in darkness for four days. The colony diameter was then measured and mycelial growth inhibition (MGI) calculated relative to the untreated control. There were four replicates for each M. cannonballus isolate.

\section{Virulence test}

The virulence of the $M$. cannonballus isolates was determined using a method described by Stanghellini et al. (2000) with some modifications. Soil (fine sandy loam, $\mathrm{pH}$ 6.5) was passed through a $2-\mathrm{mm}$ mesh screen, and allowed to air-dry for $72 \mathrm{~h}$. This soil was autoclaved for $30 \mathrm{~min}$, allowed to air dry for $24 \mathrm{~h}$, and subsequently autoclaved for $30 \mathrm{~min}$. Samples (40 g) of autoclaved soil were dispensed into polypropylene tubes $(11.5 \mathrm{~cm}$ long and $3.0 \mathrm{~cm}$ diameter) and then infested artificially with $2 \mathrm{ml}$ of ascospore suspensions $\left(1.0 \times 10^{4}\right.$ ascospores $\left./ \mathrm{mL}\right)$ that were obtained from 45-day-old V8-juice agar cultures of the M. cannonballus isolates. The control consisted of soil tubes with sterile distilled water without the presence of ascospores. A two-day-old melon (yellow type, cv. Mandacaru F1) seedling (pre-germinated on water agar) was transplanted into each tube. Seeded tubes were placed in test-tube racks, transferred to growth chambers (12-h photoperiod), and incubated at $28^{\circ} \mathrm{C}$ and $65 \%$ relative humidity for 21 days. Subsequent to transplant, all tubes were irrigated with sterile distilled water $(10 \mathrm{~mL})$ at threeday intervals. There were four replicates for each isolate, each consisting of eight seeded tubes (32 seeded tubes per isolate).

At the end of the experiment, the seedlings were removed from the tubes, and the root system of each seedling was gently washed in tap water and rated for disease severity based on the following scale adapted from Bruton et al. (2000): $0=$ no discoloration or reduction of root mass; $1=$ slight discoloration with up to $30 \%$ root mass reduction; $2=$ moderate discoloration with up to $50 \%$ root mass reduction; $3=$ severe discoloration with up to $50 \%$ root mass reduction; and $4=$ root mass reduction greater than $90 \%$. The quantification of root mass reduction was based on the root mass presented by control plants. Small pieces of representative root tissues of each seedling were surface sterilized for $1 \mathrm{~min}$ in $1.5 \% \mathrm{NaOCl}$, washed twice with sterile distilled water and plated onto PDA amended with $0.5 \mathrm{~g} / \mathrm{L}$ of streptomycin sulfate. The pathogen was reisolated from all inoculated seedlings, while no fungus was isolated from controls. The severity data were processed by McKinney's formula (McKinney, 1923), which generates a numeric disease severity index (DSI) for each repetition: DSI $=(\Sigma v n) /(N V) \times 100$, where $v$ represents the numeric value of the class, $n$ is the number of plants assigned to the class, $N$ is the total number of the plants in the replication and $V$ is the numeric value of the highest class.

\section{Data analyses}

One-way analyses of variance (ANOVA) were conducted with data obtained from experiments on mycelial growth, and perithecia and ascospore production at different temperatures, as well as those obtained in sensitivity to fluazinam and virulence experiments to analyze potential trial-treatment interactions. In all cases, ANOVA analyses indicated that the data between the two types of experiments were similar $(\mathrm{P}>0.05)$, so data of all variables from both experiments were combined.

Firstly, a univariate analysis was performed to identify groups of isolates. Data on disease severity (DSI), mycelial growth rate (MGR) and mycelial growth inhibition (MGI) were transformed into $(x+0.5)^{1 / 2}$, while data on perithecia production (PP) and ascospore production (AP) were transformed into $\log (\mathrm{x}+1)$ and subjected to ANOVA, and the means were compared by the Scott-Knott grouping test $(\mathrm{P}=0.05)$. Then, the correlations between the variables of fitness components (MGR, PP, AP, MGI and DSI) were evaluated by the analysis of Pearson correlation $(\mathrm{P}=0.01)$. The univariate and correlation analyses were performed using SAEG 9.1 software (Universidade Federal de Viçosa). Finally, using all variables, a principal component analysis was performed and followed by nested ANOVA with the values of scores (Bratchell, 1989). The nested model was 
fitted to the data: $\left.Y_{i j k l}=\mu+\alpha_{i}+\beta_{j(i)}+\gamma_{k(j(i))}+\varepsilon_{1(i j k}\right)$, where: $Y_{i j k l}$ $=$ dependent variable; $\mu=$ mean, $\alpha_{i}=$ effect of the production area, $\beta_{\mathrm{j}(\mathrm{i})}=$ effect of site nested within area, $\gamma_{\mathrm{i}(\mathrm{j}(\mathrm{k}))}=$ effect of isolate nested within the site within the area, and e $\varepsilon_{1(\mathrm{ijk})}=$ experimental error. The analysis was performed with the $\mathrm{R}$ package (R Development Core Team, 2012). Expectations of mean square were manually estimated in order to define the proper error terms to test each component of the model (Kuehl, 1994).

\section{RESULTS}

\section{Mycelial growth, and perithecia and ascospore} production at different temperatures

Monosporascus cannonballus isolates differed in mycelial growth rate (MGR) in PDA, regardless of the temperature considered. Using the Scott-Knott univariate grouping test, three groups of isolates at $22^{\circ} \mathrm{C}$ and $28^{\circ} \mathrm{C}$, and two groups at $38^{\circ} \mathrm{C}$ were revealed (Table 2). At $22^{\circ} \mathrm{C}$ the mean MGR was $19.7 \mathrm{~mm} /$ day and the values of this variable ranged from 0.0 to $27.1 \mathrm{~mm} /$ day. The isolate CMM-2411 showed no mycelial growth at this temperature. MGR values of $\geq 20 \mathrm{~mm} /$ day were observed in $56.1 \%$ of the isolates incubated at $22^{\circ} \mathrm{C}$. At $28^{\circ} \mathrm{C}$, the mean MGR was $23.8 \mathrm{~mm} /$ day and the values ranged between 3.5 and 33.7 $\mathrm{mm} /$ day. $\mathrm{MGR} \geq 20 \mathrm{~mm} /$ day were observed in $78.9 \%$ of the isolates. At $38^{\circ} \mathrm{C}$, the mean MGR was $8.8 \mathrm{~mm} /$ day, the values ranged between 0.5 and $16.3 \mathrm{~mm} /$ day, and $61.4 \%$ of the isolates showed MGR up to $10 \mathrm{~mm} /$ day. The remaining isolates $(38.6 \%)$ had growth rates over $10 \mathrm{~mm} /$ day.

Most M. cannonballus isolates produced perithecia after 45 days of incubation at $22^{\circ} \mathrm{C}$ and $28^{\circ} \mathrm{C}$, while none of them produced perithecia at $38^{\circ} \mathrm{C}$ (Table 2). Regarding the number of perithecia produced (PP), three distinct groups of isolates were observed at $22^{\circ} \mathrm{C}$ and $28^{\circ} \mathrm{C}$. At $22^{\circ} \mathrm{C}$, the mean PP value was 38.7 perithecia $/ \mathrm{cm}^{3} ; 24$ isolates $(42.1 \%)$ did not produce perithecia, and $54.4 \%$ produced between 50 and 200 perithecia $/ \mathrm{cm}^{3}$. At $22^{\circ} \mathrm{C}$, only the isolates $\mathrm{CMM}$ 2418 and CMM-2435 produced more than 200 perithecia/ $\mathrm{cm}^{3}$. At $28^{\circ} \mathrm{C}$, the mean PP was 126.5 perithecia $/ \mathrm{cm}^{3}$ and the values ranged between 0.5 and 279.7 perithecia $/ \mathrm{cm}^{3}$. Only $10.5 \%$ of the isolates produced up to 25 perithecia/ $\mathrm{cm}^{3} ; 28.1 \%$ produced between 50 and 100 perithecia $/ \mathrm{cm}^{3}$; $43.9 \%$ produced between 101 and 200 perithecia $/ \mathrm{cm}^{3}$; and $17.5 \%$ produced more than 200 perithecia $/ \mathrm{cm}^{3}$.

When evaluating the number of ascospores produced (AP) after 50 days of incubation at $22^{\circ} \mathrm{C}$ and $28^{\circ} \mathrm{C}$, the formation of two and three distinct groups was observed, respectively (Table 2). At $22^{\circ} \mathrm{C}$, the mean AP was of 20.0 ascospores/perithecia and the values of this variable ranged between 0.0 and 110.0 ascospores/perithecia. At this temperature, $35.1 \%$ of the isolates did not produce ascospores; one isolate (CMM-2451) produced more than 100 ascospores/perithecia; $54.4 \%$ produced from 0.1 to 50 ascospores/perithecia and $8.8 \%$ produced between 51 and 100 ascospores/perithecia. At $28^{\circ} \mathrm{C}$, the mean AP was 39.1 ascospores/perithecia and the values ranged between 0.1 and 165.1 ascospores/perithecia. Only $10.5 \%$ of the isolates produced more than 100 ascospores/perithecia, while $24.6 \%$ produced between 51 and 100 ascospores/perithecia, and $64.9 \%$ produced from 0.1 to 50 ascospores/perithecia.

\section{Sensitivity to the fungicide fluazinam}

Inhibition of mycelial growth (MGI) was observed in all 57 isolates of $M$. cannonballus when exposed to 10 $\mu \mathrm{g}$ a.i./L of fluazinam (Table 2). Seven distinct groups of isolates were observed by Scott-Knott grouping test. The mean MGI was $56.6 \%$ and the values ranged from 5.1 to $91.7 \% ; 59.6 \%$ of the isolates had MGI levels between 31 and $75 \%$, and $28.1 \%$ showed MGI above $75 \%$. Only two isolates (3.5\%) showed MGI levels below $10 \%$.

\section{Virulence test}

All M. cannonballus isolates were pathogenic to melon seedlings cv. Mandacaru F1. There were differences $(\mathrm{P} \leq 0.05)$ among the isolates regarding disease severity (DSI). The average DSI value was 62.1\%. Using ScottKnott grouping test it was possible to distinguish five groups of isolates. DSI values between 41 and $80 \%$ were induced by $64.9 \%$ of the isolates, while $21.1 \%$ induced DSI values above $80 \%$ and only $5.3 \%$ of isolates showed values below 20\% (Table 2).

Significant correlation was observed only between $\mathrm{PP}$ at $28^{\circ} \mathrm{C}$ and DSI $(\mathrm{r}=0.3725 ; \mathrm{P}=0.0043)$. By univariate analysis, the formation of groups of similarity of the isolates of $M$. cannonballus within each variable was not limited by the site or the production area of origin of each isolate, given that in most situations, different isolates from the same site were distributed into distinct groups of similarity (Table 2).

Using principal components analysis, the first four main components accounted for only $55.6 \%$ of total variance and no clustering of isolates was clearly identified. Thus, it was not possible to establish associations or patterns that would allow the isolates to be grouped. The nested ANOVA on the scores of the principal components revealed that the variation was mainly due to differences among isolates $(\mathrm{F}=2.04 * *$ to $8.82 * *)$. There was no effect of production site and/or area.

\section{DISCUSSION}

The $57 \mathrm{M}$. cannonballus isolates from northeastern Brazil included in this study showed variability in fitness components. This is in agreement with the observations of Martyn and Miller (1996) and with the results of a study conducted with Spanish and Tunisian isolates of this fungus (Armengol et al., 2011). Univariate and multivariate analyses revealed that this variation was mainly due to differences among isolates and there was no effect of production site and/or area.

The highest rates of mycelial growth at $28^{\circ} \mathrm{C}$ were agreement with previous reports from Israel (Pivonia 
TABLE 2 - Mycelial growth rate (MGR), perithecia production (PP) and ascospore (AP) production at different temperatures, mycelial growth inhibition by fungicide fluazinam (MGI) and disease severity induced to melon seedlings (DSI) by 57 isolates of Monosporascus cannonballus from northeastern Brazil.

\begin{tabular}{|c|c|c|c|c|c|c|c|c|c|}
\hline \multirow[t]{2}{*}{$\begin{array}{c}\text { Code } \\
(\mathrm{CMM})^{1}\end{array}$} & \multicolumn{3}{|c|}{$\begin{array}{c}\text { MGR }^{2} \\
\text { (mm/day) }\end{array}$} & \multicolumn{2}{|c|}{$\begin{array}{c}\mathbf{P P}^{2} \\
\text { (perithecia/ } / \mathrm{cm}^{3} \text { ) }\end{array}$} & \multicolumn{2}{|c|}{$\begin{array}{c}\mathrm{AP}^{2} \\
\text { (ascospores/perithecia) }\end{array}$} & \multirow[t]{2}{*}{$\begin{array}{c}\mathrm{MGI}^{2} \\
(\%)\end{array}$} & \multirow[t]{2}{*}{$\begin{array}{l}\mathrm{DSI}^{2} \\
(\%)\end{array}$} \\
\hline & $22^{\circ} \mathrm{C}$ & $28^{\circ} \mathrm{C}$ & $38^{\circ} \mathrm{C}$ & $22^{\circ} \mathrm{C}$ & $28^{\circ} \mathrm{C}$ & $22^{\circ} \mathrm{C}$ & $28^{\circ} \mathrm{C}$ & & \\
\hline 2362 & $18.9 \mathrm{a}$ & $30.7 \mathrm{a}$ & $6.2 \mathrm{~b}$ & $9.9 \mathrm{c}$ & $89.4 \mathrm{~b}$ & $6.5 \mathrm{c}$ & $24.9 \mathrm{~b}$ & $62.1 \mathrm{c}$ & $75.0 \mathrm{~b}$ \\
\hline 2363 & $20.0 \mathrm{a}$ & $27.6 \mathrm{a}$ & $11.8 \mathrm{a}$ & $64.4 \mathrm{~b}$ & $182.6 \mathrm{a}$ & $15.4 \mathrm{c}$ & $26.8 \mathrm{~b}$ & $73.8 \mathrm{~b}$ & $65.6 \mathrm{~b}$ \\
\hline 2365 & $24.7 \mathrm{a}$ & $25.2 \mathrm{a}$ & $9.0 \mathrm{a}$ & $0.0 \mathrm{c}$ & $24.8 \mathrm{c}$ & $0.0 \mathrm{c}$ & $3.2 \mathrm{~b}$ & $31.7 \mathrm{e}$ & $75.0 \mathrm{~b}$ \\
\hline 2369 & $22.4 \mathrm{a}$ & $21.3 \mathrm{a}$ & $16.3 \mathrm{a}$ & $99.2 \mathrm{a}$ & $234.0 \mathrm{a}$ & $41.3 \mathrm{c}$ & $4.1 \mathrm{~b}$ & $91.6 \mathrm{a}$ & $65.6 \mathrm{~b}$ \\
\hline 2370 & $23.6 \mathrm{a}$ & $30.3 \mathrm{a}$ & $4.0 \mathrm{~b}$ & $37.5 \mathrm{~b}$ & $136.2 \mathrm{a}$ & $0.0 \mathrm{c}$ & $0.4 \mathrm{~b}$ & $47.9 \mathrm{~d}$ & $40.6 \mathrm{c}$ \\
\hline 2371 & $27.1 \mathrm{a}$ & $18.1 \mathrm{a}$ & $7.9 \mathrm{~b}$ & $69.3 \mathrm{~b}$ & $176.7 \mathrm{a}$ & $28.2 \mathrm{c}$ & $147.0 \mathrm{a}$ & $47.8 \mathrm{~d}$ & $75.0 \mathrm{~b}$ \\
\hline 2372 & $24.0 \mathrm{a}$ & $24.5 \mathrm{a}$ & $15.4 \mathrm{a}$ & $0.0 \mathrm{c}$ & $170.5 \mathrm{a}$ & $0.0 \mathrm{c}$ & $56.7 \mathrm{~b}$ & $86.8 \mathrm{a}$ & $50.0 \mathrm{c}$ \\
\hline 2376 & $16.5 \mathrm{a}$ & $19.1 \mathrm{a}$ & $7.4 \mathrm{~b}$ & $188.9 \mathrm{a}$ & $103.8 \mathrm{a}$ & $98.5 \mathrm{a}$ & $51.7 \mathrm{~b}$ & $82.8 \mathrm{a}$ & $68.8 \mathrm{~b}$ \\
\hline 2379 & $20.2 \mathrm{a}$ & $27.2 \mathrm{a}$ & $5.4 \mathrm{~b}$ & $67.6 \mathrm{~b}$ & $87.8 \mathrm{~b}$ & $14.9 \mathrm{c}$ & $9.9 \mathrm{~b}$ & 80.9 a & $37.5 \mathrm{c}$ \\
\hline 2380 & $19.4 \mathrm{a}$ & $14.3 \mathrm{~b}$ & $4.2 \mathrm{~b}$ & $0.0 \mathrm{c}$ & $100.5 \mathrm{a}$ & $0.0 \mathrm{c}$ & $165.1 \mathrm{a}$ & $50.0 \mathrm{~d}$ & $56.3 \mathrm{~b}$ \\
\hline 2381 & $25.3 \mathrm{a}$ & $11.5 \mathrm{~b}$ & $9.7 \mathrm{a}$ & $163.0 \mathrm{a}$ & $279.7 \mathrm{a}$ & $32.2 \mathrm{c}$ & $3.2 \mathrm{~b}$ & $50.0 \mathrm{~d}$ & $91.7 \mathrm{a}$ \\
\hline 2382 & $26.3 \mathrm{a}$ & $9.2 \mathrm{~b}$ & $2.0 \mathrm{~b}$ & $0.0 \mathrm{c}$ & $8.7 \mathrm{c}$ & $0.0 \mathrm{c}$ & $0.4 \mathrm{~b}$ & $50.0 \mathrm{~d}$ & $18.8 \mathrm{~d}$ \\
\hline 2386 & $16.5 \mathrm{a}$ & $22.4 \mathrm{a}$ & $1.3 \mathrm{~b}$ & $37.2 \mathrm{~b}$ & $78.6 \mathrm{~b}$ & $0.0 \mathrm{c}$ & $23.1 \mathrm{~b}$ & $57.8 \mathrm{~d}$ & $65.6 \mathrm{~b}$ \\
\hline 2387 & $22.1 \mathrm{a}$ & $33.7 \mathrm{a}$ & $11.5 \mathrm{a}$ & $97.2 \mathrm{a}$ & $98.9 \mathrm{a}$ & $36.8 \mathrm{c}$ & $30.4 \mathrm{~b}$ & $85.2 \mathrm{a}$ & $46.9 \mathrm{c}$ \\
\hline 2389 & $23.7 \mathrm{a}$ & $21.4 \mathrm{a}$ & $6.0 \mathrm{~b}$ & $0.0 \mathrm{c}$ & $78.2 \mathrm{~b}$ & $14.3 \mathrm{c}$ & $66.3 \mathrm{a}$ & $88.0 \mathrm{a}$ & $93.8 \mathrm{a}$ \\
\hline 2390 & $22.9 \mathrm{a}$ & $32.3 \mathrm{a}$ & $9.4 \mathrm{a}$ & $56.8 \mathrm{~b}$ & $116.3 \mathrm{a}$ & $13.7 \mathrm{c}$ & $3.9 \mathrm{~b}$ & $58.1 \mathrm{~d}$ & $68.8 \mathrm{~b}$ \\
\hline 2391 & $12.7 \mathrm{a}$ & $22.2 \mathrm{a}$ & $3.8 \mathrm{~b}$ & $66.6 \mathrm{~b}$ & $98.3 \mathrm{a}$ & $33.2 \mathrm{c}$ & $39.5 \mathrm{~b}$ & $34.3 \mathrm{e}$ & $75.0 \mathrm{~b}$ \\
\hline 2394 & $21.6 \mathrm{a}$ & $24.6 \mathrm{a}$ & $9.4 \mathrm{a}$ & $3.3 \mathrm{c}$ & $230.7 \mathrm{a}$ & $0.0 \mathrm{c}$ & $19.4 \mathrm{~b}$ & $31.5 \mathrm{e}$ & $75.0 \mathrm{~b}$ \\
\hline 2395 & $24.1 \mathrm{a}$ & $28.2 \mathrm{a}$ & $12.1 \mathrm{a}$ & $75.3 \mathrm{~b}$ & $94.3 \mathrm{a}$ & $5.1 \mathrm{c}$ & $34.6 \mathrm{~b}$ & $50.0 \mathrm{~d}$ & $46.9 \mathrm{c}$ \\
\hline 2396 & $1.9 \mathrm{c}$ & $27.8 \mathrm{a}$ & $6.9 \mathrm{~b}$ & $113.3 \mathrm{a}$ & $115.5 \mathrm{a}$ & $9.2 \mathrm{c}$ & $9.9 \mathrm{~b}$ & $66.4 \mathrm{c}$ & $56.3 \mathrm{~b}$ \\
\hline 2397 & $20.2 \mathrm{a}$ & $31.5 \mathrm{a}$ & $14.7 \mathrm{a}$ & $99.7 \mathrm{a}$ & $226.3 \mathrm{a}$ & $10.8 \mathrm{c}$ & $51.2 \mathrm{~b}$ & $35.8 \mathrm{e}$ & $81.3 \mathrm{a}$ \\
\hline 2401 & $18.6 \mathrm{a}$ & $19.1 \mathrm{a}$ & $10.1 \mathrm{a}$ & $115.5 \mathrm{a}$ & $116.6 \mathrm{a}$ & $22.5 \mathrm{c}$ & $7.0 \mathrm{~b}$ & $69.1 \mathrm{c}$ & $62.5 \mathrm{~b}$ \\
\hline 2402 & $20.2 \mathrm{a}$ & $8.3 \mathrm{~b}$ & $4.9 \mathrm{~b}$ & $145.3 \mathrm{a}$ & $162.7 \mathrm{a}$ & $91.4 \mathrm{a}$ & $11.9 \mathrm{~b}$ & $88.6 \mathrm{a}$ & $90.6 \mathrm{a}$ \\
\hline 2403 & $23.5 \mathrm{a}$ & $30.0 \mathrm{a}$ & $0.5 \mathrm{~b}$ & $117.2 \mathrm{a}$ & $164.4 \mathrm{a}$ & $0.0 \mathrm{c}$ & $82.6 \mathrm{a}$ & $55.6 \mathrm{~d}$ & $59.4 \mathrm{~b}$ \\
\hline 2405 & $24.2 \mathrm{a}$ & $32.2 \mathrm{a}$ & $15.9 \mathrm{a}$ & $0.0 \mathrm{c}$ & $70.7 \mathrm{a}$ & $0.0 \mathrm{c}$ & $107.4 \mathrm{a}$ & $51.6 \mathrm{~d}$ & $3.1 \mathrm{e}$ \\
\hline 2408 & $23.7 \mathrm{a}$ & $23.9 \mathrm{a}$ & $10.0 \mathrm{a}$ & $0.0 \mathrm{c}$ & $225.5 \mathrm{a}$ & $34.7 \mathrm{c}$ & $17.5 \mathrm{~b}$ & $55.2 \mathrm{~d}$ & $65.6 \mathrm{~b}$ \\
\hline 2411 & $0.0 \mathrm{c}$ & $6.6 \mathrm{~b}$ & $3.7 \mathrm{~b}$ & $0.0 \mathrm{c}$ & $8.7 \mathrm{c}$ & $0.0 \mathrm{c}$ & $0.3 \mathrm{~b}$ & $22.7 \mathrm{f}$ & $3.8 \mathrm{e}$ \\
\hline 2412 & $17.3 \mathrm{a}$ & $3.5 \mathrm{c}$ & $1.7 \mathrm{~b}$ & $0.0 \mathrm{c}$ & $2.3 \mathrm{c}$ & $0.0 \mathrm{c}$ & $2.5 \mathrm{~b}$ & $5.9 \mathrm{~g}$ & $71.9 \mathrm{~b}$ \\
\hline 2414 & $24.0 \mathrm{a}$ & $16.1 \mathrm{~b}$ & $5.7 \mathrm{~b}$ & $0.0 \mathrm{c}$ & $99.1 \mathrm{a}$ & $0.0 \mathrm{c}$ & $53.0 \mathrm{~b}$ & $53.0 \mathrm{~d}$ & $59.4 \mathrm{~b}$ \\
\hline 2418 & $22.5 \mathrm{a}$ & $23.3 \mathrm{a}$ & $9.3 \mathrm{a}$ & $256.8 \mathrm{a}$ & $232.7 \mathrm{a}$ & $24.2 \mathrm{c}$ & $57.0 \mathrm{~b}$ & $53.6 \mathrm{~d}$ & $90.6 \mathrm{a}$ \\
\hline 2421 & $18.0 \mathrm{a}$ & $23.6 \mathrm{a}$ & $7.1 \mathrm{~b}$ & $138.5 \mathrm{a}$ & $88.6 \mathrm{~b}$ & $47.2 \mathrm{~b}$ & $144.0 \mathrm{a}$ & $91.7 \mathrm{a}$ & $71.9 \mathrm{~b}$ \\
\hline 2422 & $26.2 \mathrm{a}$ & $27.0 \mathrm{a}$ & $6.2 \mathrm{~b}$ & $122.0 \mathrm{a}$ & $0.5 \mathrm{c}$ & $2.3 \mathrm{c}$ & $12.0 \mathrm{~b}$ & $66.5 \mathrm{c}$ & $75.0 \mathrm{~b}$ \\
\hline 2427 & $14.7 \mathrm{a}$ & $26.9 \mathrm{a}$ & $13.2 \mathrm{a}$ & $101.3 \mathrm{a}$ & $228.0 \mathrm{a}$ & $48.9 \mathrm{~b}$ & $14.0 \mathrm{~b}$ & $41.5 \mathrm{~d}$ & $50.0 \mathrm{c}$ \\
\hline 2429 & $12.9 \mathrm{a}$ & $23.5 \mathrm{a}$ & $9.8 \mathrm{a}$ & $0.0 \mathrm{c}$ & $221.0 \mathrm{a}$ & $0.0 \mathrm{c}$ & $4.1 \mathrm{~b}$ & $85.7 \mathrm{a}$ & $100.0 \mathrm{a}$ \\
\hline 2430 & $14.4 \mathrm{a}$ & $23.2 \mathrm{a}$ & $2.4 \mathrm{~b}$ & $80.8 \mathrm{~b}$ & $118.0 \mathrm{a}$ & $2.7 \mathrm{c}$ & $26.1 \mathrm{~b}$ & $18.3 \mathrm{f}$ & $62.5 \mathrm{~b}$ \\
\hline 2431 & $19.1 \mathrm{a}$ & $24.2 \mathrm{a}$ & $12.9 \mathrm{a}$ & $51.3 \mathrm{~b}$ & $101.1 \mathrm{a}$ & $7.6 \mathrm{c}$ & $19.4 \mathrm{~b}$ & $53.4 \mathrm{~d}$ & $46.9 \mathrm{c}$ \\
\hline 2434 & $24.8 \mathrm{a}$ & $26.4 \mathrm{a}$ & $8.9 \mathrm{a}$ & $0.0 \mathrm{c}$ & $68.2 \mathrm{~b}$ & $0.0 \mathrm{c}$ & $12.1 \mathrm{~b}$ & $50.0 \mathrm{~d}$ & $68.8 \mathrm{~b}$ \\
\hline 2435 & $19.2 \mathrm{a}$ & $27.7 \mathrm{a}$ & $10.2 \mathrm{a}$ & $202.5 \mathrm{a}$ & $85.1 \mathrm{~b}$ & $9.5 \mathrm{c}$ & $0.9 \mathrm{~b}$ & $77.2 \mathrm{~b}$ & $100.0 \mathrm{a}$ \\
\hline 2436 & $21.4 \mathrm{a}$ & $23.8 \mathrm{a}$ & $10.8 \mathrm{a}$ & $0.0 \mathrm{c}$ & $81.6 \mathrm{~b}$ & $22.5 \mathrm{c}$ & $2.5 \mathrm{~b}$ & $73.5 \mathrm{~b}$ & $75.0 \mathrm{~b}$ \\
\hline 2437 & $18.8 \mathrm{a}$ & $32.0 \mathrm{a}$ & $14.3 \mathrm{a}$ & $0.0 \mathrm{c}$ & $125.1 \mathrm{a}$ & $28.9 \mathrm{c}$ & $65.6 \mathrm{a}$ & $52.2 \mathrm{~d}$ & $81.3 \mathrm{a}$ \\
\hline 2438 & $17.9 \mathrm{a}$ & $29.4 \mathrm{a}$ & $8.6 \mathrm{a}$ & $0.0 \mathrm{c}$ & $130.1 \mathrm{a}$ & $15.4 \mathrm{c}$ & $34.7 \mathrm{~b}$ & $79.3 \mathrm{a}$ & $15.6 \mathrm{~d}$ \\
\hline 2439 & $20.4 \mathrm{a}$ & $25.3 \mathrm{a}$ & $8.4 \mathrm{a}$ & $160.8 \mathrm{a}$ & $8.7 \mathrm{c}$ & $28.4 \mathrm{c}$ & $0.1 \mathrm{~b}$ & $50.0 \mathrm{~d}$ & $31.3 \mathrm{c}$ \\
\hline 2441 & $25.0 \mathrm{a}$ & $25.9 \mathrm{a}$ & $10.8 \mathrm{a}$ & $0.0 \mathrm{c}$ & $141.6 \mathrm{a}$ & $2.5 \mathrm{c}$ & $1.9 \mathrm{~b}$ & $68.6 \mathrm{c}$ & $40.6 \mathrm{c}$ \\
\hline 2443 & $14.5 \mathrm{a}$ & $23.7 \mathrm{a}$ & $6.7 \mathrm{~b}$ & $0.0 \mathrm{c}$ & $117.4 \mathrm{a}$ & $0.0 \mathrm{c}$ & $57.6 \mathrm{~b}$ & $84.1 \mathrm{a}$ & $93.8 \mathrm{a}$ \\
\hline 2444 & $15.8 \mathrm{a}$ & $24.2 \mathrm{a}$ & $7.8 \mathrm{~b}$ & $125.1 \mathrm{a}$ & $69.8 \mathrm{~b}$ & $92.7 \mathrm{a}$ & $15.6 \mathrm{~b}$ & $50.0 \mathrm{~d}$ & $56.3 \mathrm{~b}$ \\
\hline 2446 & $17.2 \mathrm{a}$ & $28.1 \mathrm{a}$ & $2.5 \mathrm{~b}$ & $0.0 \mathrm{c}$ & $154.4 \mathrm{a}$ & $0.0 \mathrm{c}$ & $2.8 \mathrm{~b}$ & $90.2 \mathrm{a}$ & $59.4 \mathrm{~b}$ \\
\hline 2448 & $22.0 \mathrm{a}$ & $12.1 \mathrm{~b}$ & $12.1 \mathrm{a}$ & $0.0 \mathrm{c}$ & $135.7 \mathrm{a}$ & $0.0 \mathrm{c}$ & $103.4 \mathrm{a}$ & $18.7 \mathrm{f}$ & $34.4 \mathrm{c}$ \\
\hline 2449 & $16.5 \mathrm{a}$ & $21.9 \mathrm{a}$ & $8.8 \mathrm{a}$ & $94.2 \mathrm{a}$ & $133.2 \mathrm{a}$ & $52.3 \mathrm{~b}$ & $46.7 \mathrm{~b}$ & $19.8 \mathrm{f}$ & $50.0 \mathrm{c}$ \\
\hline 2450 & $23.3 \mathrm{a}$ & $30.7 \mathrm{a}$ & $13.4 \mathrm{a}$ & $55.2 \mathrm{~b}$ & $118.0 \mathrm{a}$ & $13.9 \mathrm{c}$ & $20.3 \mathrm{~b}$ & $37.1 \mathrm{e}$ & $65.6 \mathrm{~b}$ \\
\hline 2451 & $9.0 \mathrm{~b}$ & $27.5 \mathrm{a}$ & $6.3 \mathrm{~b}$ & $171.1 \mathrm{a}$ & $52.4 \mathrm{~b}$ & $110.0 \mathrm{a}$ & $122.8 \mathrm{a}$ & $76.1 \mathrm{~b}$ & $50.0 \mathrm{c}$ \\
\hline 2452 & $18.9 \mathrm{a}$ & $28.9 \mathrm{a}$ & $13.4 \mathrm{a}$ & $0.0 \mathrm{c}$ & $168.1 \mathrm{a}$ & $54.3 \mathrm{~b}$ & $89.4 \mathrm{a}$ & $77.8 \mathrm{~b}$ & $62.5 \mathrm{~b}$ \\
\hline 2453 & $24.0 \mathrm{a}$ & $24.3 \mathrm{a}$ & $8.8 \mathrm{a}$ & $66.6 \mathrm{~b}$ & $87.0 \mathrm{~b}$ & $0.0 \mathrm{c}$ & $15.2 \mathrm{~b}$ & $31.9 \mathrm{e}$ & $68.8 \mathrm{~b}$ \\
\hline 2454 & $21.7 \mathrm{a}$ & $22.6 \mathrm{a}$ & $14.5 \mathrm{a}$ & $0.0 \mathrm{c}$ & $197.6 \mathrm{a}$ & $15.8 \mathrm{c}$ & $60.2 \mathrm{~b}$ & $16.0 \mathrm{f}$ & $46.9 \mathrm{c}$ \\
\hline 2455 & $15.2 \mathrm{a}$ & $22.5 \mathrm{a}$ & $15.5 \mathrm{a}$ & $91.8 \mathrm{a}$ & $260.6 \mathrm{a}$ & $20.9 \mathrm{c}$ & $69.0 \mathrm{a}$ & $59.3 \mathrm{~d}$ & $87.5 \mathrm{a}$ \\
\hline 2457 & $20.7 \mathrm{a}$ & $31.6 \mathrm{a}$ & $10.2 \mathrm{a}$ & $0.0 \mathrm{c}$ & $114.1 \mathrm{a}$ & $0.0 \mathrm{c}$ & $90.5 \mathrm{a}$ & $5.1 \mathrm{~g}$ & $43.8 \mathrm{c}$ \\
\hline 2466 & $18.9 \mathrm{a}$ & $25.7 \mathrm{a}$ & $11.9 \mathrm{a}$ & $0.0 \mathrm{c}$ & $221.3 \mathrm{a}$ & $30.0 \mathrm{c}$ & $33.8 \mathrm{~b}$ & $50.0 \mathrm{~d}$ & $81.3 \mathrm{a}$ \\
\hline 2467 & $21.9 \mathrm{a}$ & $28.3 \mathrm{a}$ & $12.7 \mathrm{a}$ & $0.0 \mathrm{c}$ & $166.9 \mathrm{a}$ & $0.0 \mathrm{c}$ & $55.2 \mathrm{~b}$ & $83.5 \mathrm{a}$ & $84.4 \mathrm{a}$ \\
\hline Mean & 19.7 & 23.8 & 8.8 & 58.7 & 126.5 & 20.0 & 39.1 & 56.6 & 62.1 \\
\hline
\end{tabular}

${ }^{1}$ Culture Collection of Phytopathogenic Fungi "Prof. Maria Menezes" (CMM) of the Universidade Federal Rural de Pernambuco (Recife, PE, Brazil).

${ }^{2}$ Values are means per treatment from two independent experiments. Values with the same letter within a column are not significantly $(\mathrm{P}>0.05)$ different according to Scott-Knott test. 
et al., 2002), Japan (Uematsu \& Sekiyama, 1990), Spain (Armengol et al., 2011) and the USA (Stanghellini et al., 2000), where many isolates had optimal growth between 28 and $32^{\circ} \mathrm{C}$. Growth rates of all M. cannonballus isolates at $38^{\circ} \mathrm{C}$ were similar to those obtained by Armengol et al. (2011), but differed from that found by Pivonia et al. (2002), who showed that the hyphal growth of the M. cannonballus included in this study ceased at $39^{\circ} \mathrm{C}$.

Perithecia production was greater at $28^{\circ} \mathrm{C}$, confirming previous observations (Martyn \& Miller, 1996; Waugh et al., 2003; Armengol et al., 2011), which revealed that the temperature range between 25 and $30^{\circ} \mathrm{C}$ is the most suitable temperature for perithecia production. Moreover, ascospore production was also higher at $28^{\circ} \mathrm{C}$ and we did not observe perithecia at $38^{\circ} \mathrm{C}$. All the isolates included in this study were collected from semi-arid regions, characterized by their hot summer temperatures when melon is grown. Thus, according to our results, these environmental conditions, together with the use of plastic mulches, may raise the soil temperatures to levels that favor growth and infection by M. cannonballus, and also perithecia production in diseased roots, as indicated by Martyn \& Miller (1996) and Waugh et al. (2003).

The results observed for the mycelial growth rate, perithecia production and ascospore production by $M$. cannonballus isolates at different temperatures confirm the observation that the fitness of an individual or class of phenotypes will be influenced not only by the genetically determined attributes of those individuals, but also by the environments in which they were found (Antonovics \& Alexander, 1989).

The reproductive potential of $M$. cannonballus is a significant aspect to be considered in disease management (Waugh et al., 2003). The difference between isolates according to this fitness component, as observed in this study, indicates the difference in competitive potential of the isolates. Accordingly, the reproduction rate considers relative growth rate or the number of new progeny produced by a pathogen strain and is the most common measurement of competition among pathogen strains. Pathogens with higher reproduction rates are thought to have a higher competitive ability. Pathogen strains with a higher competitive ability increase in frequency over pathogen generations and eventually dominate the experimental population (Zhan \& McDonald, 2013).

The high sensitivity of most $M$. cannonballus isolates to the fungicide fluazinam was expected, since this fungicide has not been used to control the root rot in melon production areas in the states of Ceará and Rio Grande do Norte. In studies conducted in Israel, fluazinam totally inhibited the growth of M. cannonballus in culture at concentrations of $10 \mu \mathrm{g}$ a.i./L (Cohen et al., 1999; Cohen et al., 2000). The lack of correlation between sensitivity to fungicide fluazinam and disease severity in melon indicates that there was no fitness cost in virulence associated with fungicide sensitivity. Fitness costs associated with fungicide resistance are often predicted but rarely reported (Zhan \& McDonald, 2013).

Disease severity values obtained in this study were useful in separating isolates of $M$. cannonballus into different virulence groups. This knowledge is essential for an effective breeding program (Bruton et al., 2000). Differences in virulence among isolates of $M$. cannonballus from melon in Brazil were reported previously by Andrade et al. (2005), although in this study the authors used a low number of isolates obtained from only two growing areas. Studies conducted in Japan (Uematsu \& Sekiyama, 1990) and USA (Bruton et al., 2000) also revealed variability of virulence to melon among isolates of $M$. cannonballus. The lack of a significant correlation between disease severity and most of the fitness components of $M$. cannonballus isolates may indicate that these characteristics are determined by different groups of genes, and the population is recombined spontaneously (Caten \& Newton, 2000).

The fitness variability among $M$. cannonballus isolates found in this study should be considered when possible sources of resistance are evaluated in melon breeding programs.

\section{ACKNOWLEDGEMENTS}

This research was partially funded by Coordenação de Aperfeiçoamento de Pessoal de Nível Superior - CAPES (Project 203/2009 - International Cooperation CAPESBrazil/DGU-Spain). We are thankful to Conselho Nacional de Desenvolvimento Científico e Tecnológico - CNPq for the research fellowships granted to M.P.S.C., R.S.J., E.S.G.M. and S.J.M.

\section{REFERENCES}

AGRIANUAL (2013) Anuário da Agricultura Brasileira. São Paulo, SP. Informa Economics/FNP South America.

AGROFIT (2013) Ministério da Agricultura. Available at: http:// extranet.agricultura.gov.br/agrofit_cons/principal_agrofit_cons. Accessed on September 03, 2013.

Allen DJ, Lenné JM, Waller JM (1999) Pathogen biodiversity: Its nature, characterization and consequences. In: Wood D, Lenné JM (Eds.) Agrobiodiversity: Characterization, utilization and management. Wallingford, UK. CAB International. pp. 123-153.

Andrade DEGT, Michereff SJ, Borges MAS, Araújo IB, Sales Junior R (2005) Influence of inoculum density and strains of Monosporascus cannonballus on severity of melon collapse. Summa Phytopathologica 31:173-180.

Antonovics J, Alexander HM (1989) The concept of fitness in plant fungal pathogen systems. In: Leonard KJ, Fry WE (Eds.) Plant disease epidemiology. New York, NY, USA. McGraw-Hill. pp. 185-214.

Armengol J, Alaniz S, Vicent A, Beltrán R, Abad-Campos P, PérezSierra A, García-Jiménez J, Ben Salem I, Souli M, Boughalleb N (2011) Effect of dsRNA on growth rate and reproductive potential of Monosporascus cannonballus. Fungal Biology 115:236-244. 
Ben Salem I, Correia KC, Boughalleb N, Michereff SJ, León M, AbadCampos P, García-Jiménez J, Armengol J (2013) Monosporascus eutypoides, a cause of root rot and vine decline in Tunisia, and evidence that M. cannonballus and M. eutypoides are distinct species. Plant Disease 97:737-743.

Bezerra CS, Correia KC, Câmara MPS, Sales Jr. R, Armengol J, Michereff SJ (2013) Population structure of Monosporascus cannonballus isolated from melons produced in Northeastern Brazil based on mycelial compatibility groups. Acta Scientiarum Agronomy 35:161-167.

Bratchell N (1989) Multivariate response surface modelling by principal component analysis. Journal of Chemometrics 3:579-588.

Brown JKM (2006) Surveys of variation in virulence and fungicide resistance and their application to disease control. In: Cooke BM, Jones DG, Kaye B (Eds.) The epidemiology of plant diseases. $2^{\text {nd }}$ ed. Dordrecht, The Netherlands. Springer. pp 81-115.

Bruton BD (1998) Soilborne diseases in cucurbitaceae: pathogen virulence and host resistance. In: Mccreight J(Ed.). Cucurbitaceae'98. Alexandria, USA. ASHS Press. pp. 143-166.

Bruton BD, Garcia-Jimenez J, Armengol J, Popham TW (2000) Assessment of virulence of Acremonium cucurbitacearum and Monosporascus cannonballus on Cucumis melo. Plant Disease 84:907-913.

Caten CE, Newton AC (2000) Variation in cultural characteristics, pathogenicity, vegetative compatibility and electrophoretic karyotype within field populations of Stagonospora nodorum. Plant Pathology 49:219-226.

Cluck TW, Biles CL, Duggan M, Jackson T, Carson K, Armengol J, Garcia-Jimenez J, Bruton BD (2009) Association of dsRNA to downregulation of perithecial synthesis in Monosporascus cannonballus. The Open Mycology Journal 3:9-19.

Cohen R, Pivonia S, Burger Y, Edelstein M, Gamliel A, Katan J (2000) Toward integrated management of Monosporascus wilt of melons in Israel. Plant Disease 84:496-505.

Cohen R, Pivonia S, Crosby KM, Martyn RD (2012) Advances in the biology and management of Monosporascus vine decline and wilt of melons and other cucurbits. Horticultural Reviews 39:77-120.

Cohen R, Pivonia S, Shtienberg D, Edelstein M, Raz D, Gerstl Z, Katan J (1999) Efficacy of fluazinam in suppression of Monosporascus cannonballus, the causal agent of sudden wilt of melons. Plant Disease 83:1137-1141.

Dyakov YT, Dzhavakhiya VG, Korpela T (2007) Comprehensive and Molecular Phytopathology. Amsterdam, The Netherlands. Elsevier.

Fita A, Pico B, Dias RCS, Nuez F (2009) 'Piel de Sapo' breeding lines tolerant to melon vine decline. HortScience 44:1458-1460.

Fita A, Picó B, Nuez F (2007) Melon roots under stress: melon vine decline. Plant Stress 1:93-104.

Kuehl RO (1994) Statistical Principles of Research Design and
Analysis. Belmont, USA. Duxbury Press.

Lannou C (2012) Variation and selection of quantitative traits in plant pathogens. Annual Review of Phytopathology 50:319-338.

Linde CC (2010) Population genetic analyses of plant pathogens: new challenges and opportunities. Australasian Plant Pathology 39:23-28.

Martyn RD, Miller ME (1996) Monosporascus root rot and vine decline: an emerging disease of melon worldwide. Plant Disease 80:716-725.

McKinney HH (1923) Influence of soil temperature and moisture on infection of wheat seedlings by Helminthosporium sativum. Journal of Agricultural Research 26:195-218.

Pivonia S, Cohen R, Rigel J, Katan J (2002) Effect of soil temperature on disease development in melon plants infected by Monosporascus cannonballus. Plant Pathology 51:472-479.

Pivonia S, Gerstl Z, Maduel A, Levita R, Cohen R(2010) Management of Monosporascus sudden wilt of melon by soil application of fungicides. European Journal of Plant Pathology 128:201-209.

R Development Core Team (2012) R: A Language and Environment for Statistical Computing. Available at: http://www.r-project.org/. Accessed on October 26, 2012.

Sales Jr. R, Nascimento IJB, Freitas LS, Beltrán R, Armengol J, Vicent A, García-Jiménez J, (2004) First Report of Monosporascus cannonballus on melon in Brazil. Plant Disease 88:84.

Silva KJP; Cordeito AG, Nogueira DRS, Sales Jr. R (2010) Monosporascus cannonballus: agente causal do colapso ou morte súbita do meloeiro. Revista Verde 5:11-18.

Sivanesan A (1991) Monosporascus cannonballus. Mycopathologia 114:53-54.

Stanghellini ME, Alcantara TP, Ferrin DM (2010) Germination of Monosporascus cannonballus ascospores in the rhizosphere: a hostspecific response. Canadian Journal of Plant Pathology 32:402-405.

Stanghellini ME, Kim DH, Rasmussen SL (1996) Ascospores of Monosporascus cannonballus: germination and distribution in cultivated and desert soils in Arizona. Phytopathology 86:509-514.

Stanghellini ME, Kim DH, Waugh M (2000) Microbe-mediated germination of ascospores of Monosporascus cannonballus. Phytopathology 90:243-247.

Uematsu S, Sekiyama K (1990). Comparison of morphological characteristics and pathogenicity of Monosporascus cannonballus Pollack and Uecker collected in Japan, distribution in melon plants with root rot symptoms and survival in soils under laboratory conditions. Soil Microorganisms 35:7-12.

Waugh MM, Kim DH, Ferrin DM, Stanghellini ME (2003) Reproductive potential of Monosporascus cannonballus. Plant Disease 87:45.50

Zhan J, McDonald BA (2013) Experimental measures of pathogen competition and relative fitness. Annual Review of Phytopathology 51:131-153. 